\title{
Baclofen with famotidine for intractable hiccups
}

\author{
K. Mariën, D. Havlak
}

To the Editor:

Hiccups, which are caused by involuntary contractions of inspiratory muscles, can cause discomfort and when intractable, may, potentially, be a severe condition. Chronic hiccups have been treated with a variety of pharmacological agents including chlorpromazine, metaclopromide, nifedipine, haloperidol, lidocaine, baclofen and various gastric acid secretion suppressors [1-3]. This neurorespiratory disorder is rare, with the few case reports available providing some information regarding treatment [1-3]. Encouraging results were provided in 1995 by a chronic hiccup study, presented in the Journal by GuELAUD et al. [4], using baclofen in patients showing no gastro-oesophageal disease and using cisapride and omeprazole (with the eventual possible addition of baclofen) in patients with gastro-oesophageal abnormalities. Although the presence of hiccups and gastro-oesophageal reflux in the same patient may still be considered coincidental [5], case report evidence is becoming available to indicate that a causal relationship may exist $[1,4,6]$.

Recently, a healthy male aged 36 yrs was diagnosed with intractable hiccups for 6 days. The patient had contractions at the rate of one every $3 \mathrm{~s}$ with no relief available from methods used to eliminate nonpathological hiccups. A sustained Valsalva manoeuvre worked on occasion, but relapse would occur with gastro-oesophageal reflux symptoms. The individual was given a single dose of chlorpromazine with no effect. Famotidine was initiated at $40 \mathrm{mg} \cdot \mathrm{day}^{-1}$ and concomitantly, baclofen was provided at an initial dose of $15 \mathrm{mg} \cdot \mathrm{day}^{-1}(5$ mg every $8 \mathrm{~h}$ ). As this regimen had no effect, baclofen was increased to $20 \mathrm{mg} \cdot \mathrm{day}^{-1}(5 \mathrm{mg}$ every $6 \mathrm{~h}$ ) providing excellent relief of hiccups. Baclofen treatment was maintained for 10 days without relapse. Baclofen dosage was then reduced by increasing the dosage interval $\left(2 \mathrm{~h} \cdot \mathrm{day}^{-1}\right)$. The interval was equivalent to one half-life $(4 \mathrm{~h})$ every 2 days and continued until only one $5 \mathrm{mg}$ dose was needed during a $24 \mathrm{~h}$ period, at which time baclofen was discontinued. Aggressive treatment with famotidine was continued throughout the baclofen treatment period and was continued for an additional week at $10 \mathrm{mg} \cdot \mathrm{day}^{-1}$. Relapse has not occurred since.

This case report indicates that baclofen treatment was very effective when administered immediately with histamine $\mathrm{H}^{2}$-receptor antagonist suggesting that concomitant use can produce patient relief, and that relief is delivered more rapidly than the regimen followed by Genlaud et al. [4]. This case supports the conclusion of GENLAud et al. [4], who suggested that drug withdrawal without relapse appeared possible. The withdrawal regimen was effective, although it differed from the normal procedure followed when baclofen is used as an antispasmodic.

\section{References}

1. Duffy MC, Edmond H, Campbell K, Fulton JD. Hiccough relief with cisapride. Lancet 1992; 340: 1223.

2. Dunst MN, Margolin K, Horak D. Lidocaine for severe hiccups. N Eng J Med 1993; 329: 890-891.

3. Brigham B, Bolin T. High dose nifedipine and fludrocortisone for intractable hiccups. Med J Austral 1992; 157: 70 .

4. Guelaud C, Similowski T, Bizee J-L, et al. Baclofen therapy for chronic hiccup. Eur Resp $J$ 1995; 8: 235-237.

5. Fisher MJ, Mittal RK. Hiccups and gastroesophageal reflux: cause and effect? Dig Dis Sciences 1989; 34: 1277-1280.

6. Gluck M, Pope CE II. Chronic hiccups and gastroesophageal reflux disease: the acid perfusion test as a provocative manoeuvre. Ann Int Med 1986; 105: 221-222.

\section{K. Mariën*, D. Havlak**}

*State of Washington Dept of Health, P.O. Box 47825 , Olympia, WA 98504, USA. **Memorial Clinic, 406 Yanger Way, Suite 1, Olympia, WA 98502, USA. 
